\title{
PRIMER PROYECTO DEL TRIUNFO PARA LA BEATIFICACIÓN DE SAN FERNANDO: BERNARDO SIMÓN DE PINEDA Y JUAN DE VALDÉS LEAL (1671)
}

\author{
FÁTIMA HALCÓN ${ }^{1}$ \\ Francisco JaVIER HerRera García ${ }^{2}$ \\ Universidad de Sevilla
}

\begin{abstract}
La catedral de Sevilla, desde la baja Edad Media, puso máximo empeño en las celebraciones festivas de carácter religioso. Destacaron a lo largo de los siglos XVI y XVII las dedicadas al rey Fernando III de Castilla y León, cuyos restos conserva el templo hispalense. En este artículo damos a conocer un primer proyecto inédito del triunfo que se iba a levantar con motivo de la beatificación del rey, firmado por Juan de Valdés Leal y Bernardo Simón de Pineda, fechado en 1671. El proyecto no se realizó, pero serviría de guía al finalmente ejecutado, que guarda estrechas relaciones con el barroco internacional, tanto italiano como nórdico.
\end{abstract}

Palabras clave: Fernando III; catedral de Sevilla; Juan de Valdés Leal; Bernardo Simón de Pineda.

\section{THE FIRST PROJECT OF THE TRIUMPH FOR THE BEATIFICATION OF SAINT FERDINAND: BERNARDO SIMÓN DE PINEDA AND JUAN DE VALDÉS LEAL (1671)}

The cathedral of Seville, from the low middle ages, put special effort in festive celebrations of religious character. Throughout the sixteenth and seventeenth centuries, those dedicated to King Ferdinand III of Castile and León, whose remains preserves the Seville temple. This article presents a first unpublished project of the triumph that was going to be raised on the occasion of the canonization of the king, signed by Juan de Valdés Leal and Bernardo Simón de Pineda, dated in 1671. The project was not realized, but it would guide the finally executed, related to the proposals of the Italian and Nordic Baroque.

Key words: Fernando III; Seville Cathedral; Juan de Valdés Leal; Bernardo Simón de Pineda.

Cómo citar este artículo / Citation: Halcón, Fátima y Herrera García, Francisco Javier (2020): "Primer proyecto del triunfo para la beatificación de san Fernando: Bernardo Simón de Pineda y Juan de Valdés Leal (1671)". En: Archivo Español de Arte, vol. 93, núm. 370, Madrid, pp. 97-112. https://doi.org/10.3989/aearte.2020.07.

Dentro de las arquitecturas efímeras que se levantaron en la catedral de Sevilla con motivo de la beatificación del rey Fernando III, ocupó un lugar destacado el triunfo que se colocó en el trascoro. Su importancia quedó resaltada desde el libro que escribió Fernando de la Torre Farfán (1609-1677) donde se pormenorizaban las arquitecturas, jeroglíficos, decoraciones y distintos adornos del recinto, analizados por los distintos investigadores que se han ocupado del tema ${ }^{3}$. El

\footnotetext{
1 fhao@us.es / ORCID iD: http://orcid.org/0000-0001-6045-4694

2 fjherrera@us.es / ORCID iD: http://orcid.org/0000-0002-5032-5351

3 Torre Farfán, 1672. A lo largo de este estudio se incluirá la bibliografía al respecto. Es preciso aclarar que, si nos atenemos al breve del Papa Clemente X, de 11 de febrero de 1671, por medio del cual se concede el nuevo culto al Rey
} 
Cabildo catedralicio, responsable de las fiestas que se iban a llevar a cabo, nombró a un elenco de arquitectos, escultores y pintores para acometer las obras entre los que destacaron desde el punto de vista arquitectónico Bernardo Simón de Pineda y Juan de Valdés Leal. Ellos fueron los encargados de idear el triunfo además de los decorados para el Patio de los Naranjos. A través del proyecto que damos a conocer en este artículo, entendemos que con anterioridad al triunfo que se levantó se proyectó otro más simple que el Cabildo rechazó. Posiblemente por entender que esa primera idea no reflejaba la relevancia de la beatificación que requería de todo el boato, originalidad y gasto para semejante efeméride.

Fernando III de Castilla y León (1201-1252) estuvo unido a la historia de Sevilla desde que la conquistó en 1248, inaugurando una etapa de conmemoraciones en las tradiciones de la ciudad. La existencia de esa unidad puede comprobarse en los años que vivió el rey hasta su muerte (3005-1252) y muy especialmente desde que subió a los altares, primero como beato y finalmente, a partir de 1671, como santo. El escenario privilegiado de la unión entre el rey y la ciudad fue la catedral de Sevilla. De las honras fúnebres que le dedicaron a su muerte apenas si ha quedado constancia, solo se conoce que su cuerpo fue trasladado a la catedral donde el arzobispo don Remondo ( $i-1288)$ celebró una misa en su honor y pronunció un memorable discurso sobre sus hazañas ${ }^{4}$. El rey fue sepultado en la mezquita-catedral cuando fue cristianizada tras la conquista, reposando sus restos mortales en diversos espacios catedralicios hasta ocupar definitivamente su lugar en la Capilla de los Reyes a donde se trasladaron en $1579^{5}$. Con motivo de esa efeméride, que tuvo gran repercusión en el templo hispalense y en la ciudad, se llevó a cabo una procesión por las calles de Sevilla a la que asistieron todas las autoridades civiles y religiosas, cofradías, órdenes militares, etc. Tales celebraciones festivas están recogidos en un manuscrito de Francisco de Sigüenza (1530-1608) ${ }^{6}$, cuya primera edición fue realizada por Santiago Montoto (18901973) en 1919, quien transcribió el documento original conservado en la Biblioteca Capitular y Colombina de Sevilla ${ }^{7}$. Con posterioridad, han sido numerosos los historiadores que han analizado el traslado de los cuerpos reales acaecido el 14 de junio de 1579, por lo que existe una extensa bibliografía sobre el tema ${ }^{8}$.

El manuscrito de Sigüenza se hizo por encargo de Fernando Enríquez de Ribera, III marqués de Tarifa, gran humanista y erudito sevillano, cuya influencia está presente en el libro que manifiesta su conocimiento de las obras de otros historiadores locales como Luis de Peraza, Argote de Molina (1548-1596) o Juan de Mal Lara (1524-1571). De la obra de Sigüenza, existen varias copias. La primera, conservada en la Biblioteca Colombina, está firmada y rubricada al vuelto de la hoja $29^{9}$ y es la que edita Santiago Montoto en 1919 (sign. 58-2-47) y luego estudia y reedita García de la Concha. A finales del XVII, hacia 1698, se efectuó otra copia (sign. 59-3-33) a las que hay que añadir una tercera (sign. 33-200) de la que ya daba indicios de su existencia Montoto ${ }^{10}$.

Fernando III, en realidad lo entonces otorgado fue la beatificación del monarca. Sin embargo, de inmediato se habla de canonización, como sigue ocurriendo en la actualidad. En los años siguientes se incrementaría el culto fernandino y sería incluido en 1672 en el martirologio romano, por lo que de facto se le consideraría santo, aunque no existe una bula que reconozca esta condición. Rubio Merino, 2005. Por nuestra parte, al referirnos al proceso que abarca gran parte del XVII, expresamos "canonización", pues esa era la condición que se persigue, y para los actos de 1671 empleamos el término "beatificación".

${ }^{4}$ Primera Crónica General de España que mandó componer Alfonso X el Sabio y se continuaba bajo Sancho IV en 1289, publicada por Menéndez Pidal con la colaboración de A. G. Solalinde, M. Muñoz y J. Gómez Pérez, 1955: 773.

5 Laguna Paúl, 1998.

6 Sigüenza, 1996.

7 Montoto, 1919. El manuscrito citado tiene la signatura de la Biblioteca Capitular y Colombina (BCC), Sevilla sig. 58-2-47.

${ }^{8}$ Además de la transcripción del manuscrito, la edición crítica sobre el tema y el autor del mismo realizada por Federico García de la Concha Delgado en la publicación reseñada en la nota 4, destacamos la siguiente bibliografía. Morales, 2007b. García Bernal, 2008.

9 Esta versión es la que fue estudiada por Federico García de la Concha.

10 Sigüenza, 1996: 50. En esencia presentan el mismo contenido, salvo algunas variantes en la redacción. 


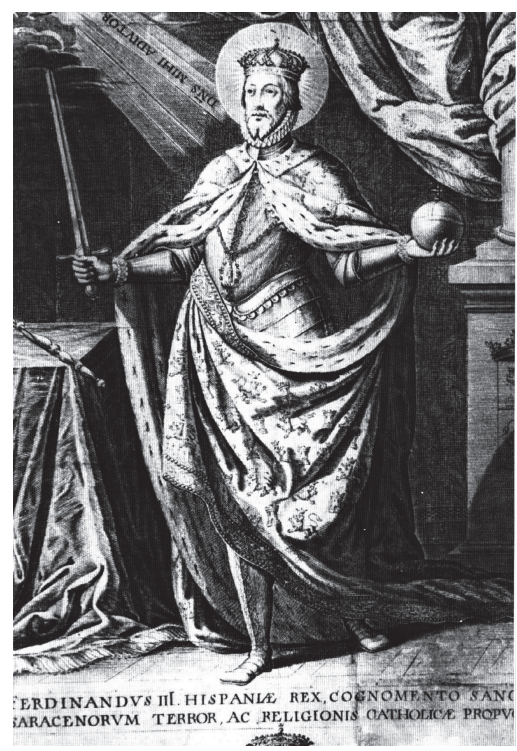

Fig. 1. Claude Audran "el viejo". Roma, 1630. Fernando III de León y Castilla. Grabado calcográfico Colección particular, Sevilla.

Sin duda, la gran celebración para conmemorar al santo rey fueron los cultos fernandinos, también con preferente acento festivo, que se hicieron con motivo de su beatificación firmiter concedida por el papa Clemente X $(1590-1676)^{11}$. El proceso de canonización del rey fue largo y costoso, aunque fue considerado santo prácticamente desde su muerte y varios papas concedieron indulgencias a los que rezaran ante su tumba ${ }^{12}$. Venerado como persona de grandes y santas virtudes, a partir de 1624 fueron iniciadas las oportunas diligencias para su proceso de beatificación. Punto de partida esencial serían las investigaciones sobre la vida y milagros de Fernando III, resultado de lo cual fue el libro de Juan de Pineda (15581637) Memorial de la Excelente Santidad y Virtudes Heroicas del Santo Rey, publicado en Sevilla en 1627. E1 cénit de ese largo historial, prolongado durante más de cuatro décadas, tuvo su momento culminante en las celebraciones que se llevaron a cabo en la catedral hispalense con motivo de su beatificación, a partir del 25 de mayo de 1671. Las solemnidades festivas unidas al ornato del exterior e interior del templo fue exponente del nivel artístico, estético y simbólico de la cultura barroca sevillana y del poderoso cabildo que de nuevo quiso demostrar la relevancia de la sede hispalense con resolución y eficacia. El principal testimonio de aquellos fastos es el citado libro de Fernando de la Torre Farfán (1609-1677), donde se describe e ilustra la mayor parte del ceremonial, los decorados, arquitecturas efímeras, jeroglíficos, emblemas, epigramas, además de las pinturas, esculturas y leyendas que formaron parte de esas solemnidades ${ }^{13}$.

Se nombró una comisión para solicitar en Roma la firma de las bulas papales con el fin de comenzar el proceso, nombrándose al canónigo Diego López de Ayala agente en Roma y a Bernardo de Toro comisionado ante la Santa Sede por el rey Felipe IV (1605-1665) ${ }^{14}$. Fue Bernardo de Toro quien obtuvo licencia para estampar la imagen de Fernando III con los atributos de santo. La imagen corresponde a la grabada por Claude Audran "el Viejo" (1597-1677) en 1630, que se convirtió en la estampa oficial en todo el proceso [fig. 1]. Como es sabido, el rey fue representado de pie, con armadura, capa de armiño adornada de castillos y leones, gola, corona real y nimbado, portando en su mano derecha la espada y en la izquierda el globo crucífero. En la mesa figura un cetro, situado a la izquierda y a la derecha una columna en cuyo pedestal están las armas de Castilla y León ${ }^{15}$. El rompimiento de gloria se sitúa en el ángulo superior izquierdo, a donde dirige la mirada el rey, con unos rayos en los que se lee la inscripción Dominus Mihi Auditor ${ }^{16}$.

Claude Audran, quizás a partir de las indicaciones de Bernardo de Toro, debió consultar algunas fuentes grabadas que le guiaran en la iconografía del rey santo. Entre los repertorios de imágenes que pudieron haberle orientado pudo estar el libro de Jacob Schrenck von Notzing

\footnotetext{
11 Rubio Merino, 2005.

12 Cintas del Bot, 1991: 24-25. Pacho Sardón, 2015. Concedieron indulgencias los papas Inocencio IV (1252), Alejandro IV (1254) y más tarde Sixto V (1590).

13 Torre Farfán, 1672. Reediciones facsímiles, 1985, 1991, 1995 entre otras.

14 Castañeda Delgado, 1994.

15 Rodríguez Moya, siguiendo a Juan de Pineda, destaca tres tipos iconográficos anteriores a la estampa de Audran: a caballo, de pie dando limosna y entronizado. Conocemos a través de sellos, el pendón de la conquista de Sevilla, algunas pinturas e iluminaciones, la versión muy extendida antes del XVII de san Fernando entronizado. Rodríguez Moya, 2006: 104-105.

16 Quiles, 1999. Wunder, 2001. Quiles, 2005: 57-102. Wunder, 2017: 76-81. Quiles, 2018: 119-150.
} 


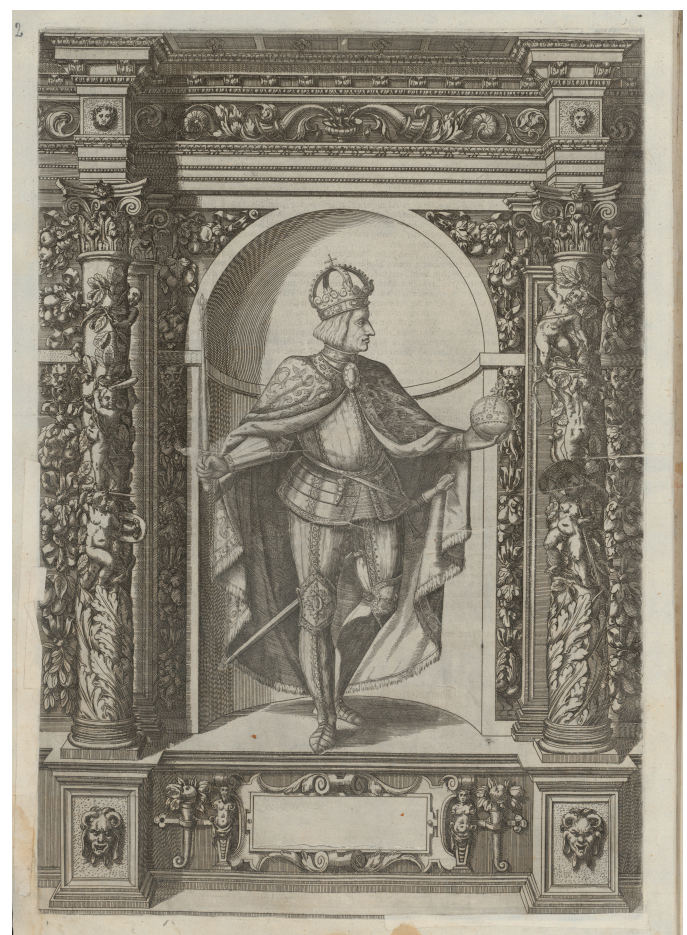

Fig. 2. G. B. Fontana. 1603. Alberto I emperador del Sacro Imperio y duque de Austria. Grabado calcográfico.

J. Schrenck von Notzing, Der Aller Durchleuchtigisten und Großmächtigen Kayser. (c) BNE, sign. ER/50.

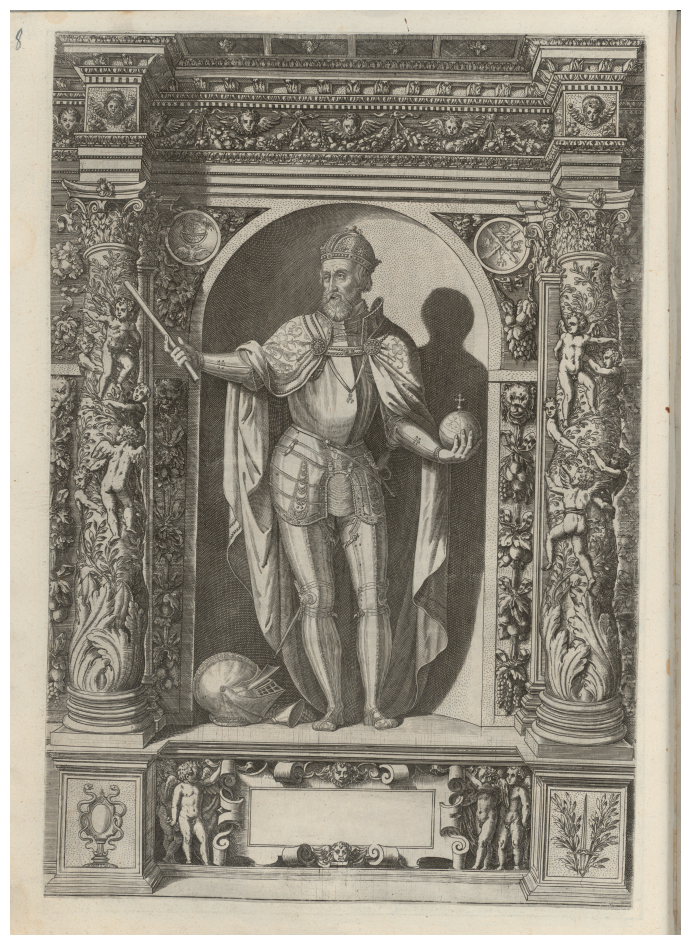

Fig. 3. G. B. Fontana. 1603. Fernando I emperador del Sacro Imperio y archiduque de Austria. Grabado calcográfico. J. Schrenck von Notzing, Der Aller Durchleuchtigisten und Großmächtigen Kayser. (C) BNE, sign. ER/50.

(1539-1612), secretario particular del archiduque Fernando de Austria, titulado Armamentarium Heroicum, publicado en Innsbruck en 1601, con grabados a partir de dibujos de Giovanni Battista Fontana (1524-1587) ${ }^{17}$. Allí son representados electores y condes palatinos desde la Edad Media, junto a emperadores del Sacro Imperio. En concreto los retratos en actitud heroica, ataviados con armadura, capa y exhibiendo el orbe y el cetro o la espada en alto, son claras referencias que se corresponden con el modelo ideado por Audran. Entre otros podemos citar las representaciones de Roberto I (1309-1356), elector y conde palatino entre 1350-1356, Federico III (1415-1493), emperador del Sacro Imperio, o Fernando I de Austria (1503-1564) [figs. 2 y 3], transmitiéndose igualmente tales improntas a la imagen fernandina realizada posteriormente por Pedro Roldán. Ello nos lleva a pensar que el libro citado debió de ser conocido por alguno de los miembros de la comisión catedralicia, posiblemente a través de Bernardo de Toro, encargándose de dictar instrucciones sobre la iconografía del futuro santo, e incluso pudo ser tenida en cuenta en los instantes previos a las fiestas de 1671, para la creación de la escultura roldanesca.

Por razones de distinta índole el proceso se retrasó hasta el 7 de febrero de 1671, fecha en la que el papa Clemente X promulgaba el Breve sobre el culto a Fernando III y reconocía su beatificación firmiter. La celebración de su subida a los altares fue la más relevante manifestación

17 La obra tuvo una edición príncipe en latín en 1601 y alemana en 1603. De la primera consta en la BNE un ejemplar con el título Augustissimorum imperatorum... (sign. ER/28). También en la misma biblioteca figura una edición alemana, J. Schrenk von Notzing, Der Aller Durchleuchtigisten und Großmächtigen Kayser, Durchleuchtigisten unnd Großmächtigen Königen und Ertzhertzogen ... durch Daniel Baur, Innsbruck, 1603 (sign. ER/50). En la Biblioteca del Palacio Real de Madrid está catalogado un ejemplar en latín de 1601, editado también en Innsbruck, con el título Augustissimorum imperatorum, serenissimorum regum, atque archiducum, illustrissimorum principum necnon Comitum, Baronum, Nobilium, aliorumque clarissimorum virorum... (sign. IX/M/132). Pelc, 2015: 124-141. 
del barroco en la ciudad, que puso de manifiesto el poder del cabildo catedralicio sevillano y de las altas jerarquías eclesiásticas. Llegada la noticia a Sevilla el 3 de marzo, se reunió el cabildo para tratar de celebrarlo convenientemente. La efeméride está recogida en Ortiz de Zúñiga (16361680), pero sobre todo en el libro ya citado que le dedicó a las fiestas Torre Farfán ${ }^{18}$.

El 3 de marzo de 1671 se nombró una diputación para la fiestas y celebraciones del nuevo santo, integrada por parte del cabildo por los canónigos Francisco Ponce de León, arcediano de Niebla, Juan de Texada y Alderete, Mateo Coello de Vicuña, Justino de Neve y Chaves y Andrés de León y Ledesma, además de los racioneros Agustín de Aguirre, Diego de la Cueva, Juan Bonifaz y Contreras y Juan de Loaysa ${ }^{19}$. Al conocerse que el rey solo había sido beatificado, se acordó que la fiesta fuese antes del 30 de mayo (fecha de su fallecimiento).

Se encargó una escultura nueva del rey cuya fuente de inspiración fue el citado grabado de Audran "el Viejo", designándose como escultor de la misma a Pedro Roldán (1624-1699), y su policromía a María Luisa de Morales (1652-1706), hija de Juan de Valdés Leal (1622-1690) ${ }^{20}$. Los comisionados más implicados en las decoraciones proyectadas para el interior y el exterior del templo catedralicio, Justino de Neve y Juan de Loaysa, avisaron a "Bartolome Murillo y a Juan de Valdes y a Pedro de Medina, maestros pintores y a Francisco Ruesta architecto y a Esteban Garcia maestro de obras y a Bernardo Simon maestro escultor para que confieran como se adornara el crucero y altar mayor y tracen el diseño que se ha de llevar a Madrid..." 21.

El canónigo encargado de hacer las gestiones en la corte, Juan de Texada, solicitó al rey 50.000 escudos para poder llevar a cabo las fiestas de beatificación, aprovechando la ocasión para exponerle la necesidad de hacer un altar y urna nueva, para colocar el cuerpo de san Fernando en la capilla real, puesto que el lugar donde se encontraba en ese momento no era el adecuado para un cuerpo santo. Juan de Texada hace referencia en la corte a los diseños que presentó en 1634 el deán Francisco de Monsalve, para levantar un lugar digno donde depositar el cuerpo real ${ }^{22}$, que debieron ser los ideados por el arquitecto de retablos y ensamblador Luis Ortiz de Vargas (1588-1649), referidos en sendos informes, uno fechado en 1634 en forma de carta dirigida sin duda al citado deán Monsalve, y que deja entrever cómo se trataba de proyectar no solo el retablo, sino también la urna o caja relicario del Santo, acompañada de un rico programa iconográfico que se extendía entre este tramo inferior y el retablo con la imagen de la Virgen de los Reyes ${ }^{23}$.

Torre Farfán indica en su obra sobre las fiestas, que algunos espacios de la catedral como la capilla mayor, dada la suntuosidad del retablo, era forzoso excluirla de "otro adorno que el propio con que esta construido su inmensurable fábrica" 24 , pero reconoce que hubo arbitrios para levantar un altar efímero sobre el pavimento aunque se suspendió el intento. Se decoró como habitualmente se adornaba en la festividad del Corpus añadiéndole un estrado con la imagen de san Fernando ${ }^{25}$. Precisando tal idea, apuntada por Torre Farfán, el manuscrito conservado en la Biblioteca Capitular y Colombina, ya citado, alude a la inicial intención, por parte de los capitulares y del comisionado Loaysa, de erigir el triunfo en aquel emplazamiento, delante del retablo mayor, encargándosele a Bernardo Simón de Pineda (1638-1702) y a Juan de Valdés. La junta recibió el 18 de marzo un diseño que presentó Bernardo Simón de Pineda, "para vestir" el altar mayor de la catedral, comisionando a Justino de Neve que hiciese las gestiones pertinentes con los artistas que fuesen a inter-

18 Ortiz de Zúñiga, 1677: 228-276. Torre Farfán, 1672.

19 Documentos Varios, 3 de marzo 1671, BCC, Sevilla, Signatura. 33-200, ff. 111-117.

20 Bernales Ballesteros, 1973: 68 y 130. Roda Peña, 2012: 192-196.

21 Documentos Varios, 3 de marzo 1671, BCC, Sevilla, Signatura, 33-200, ff. 111v. y 112r.

22 Documentos Varios, 3 de marzo 1671, BCC, Sevilla, Signatura, 33-200, f. 112v.

23 La carta, fechada el 8 de agosto de 1634 fue dada a conocer y analizada por Quiles, 1999: 217-218 y 226; Quiles, 2005: 86-87 y 151-152, mostrando, según describe, la inserción de una escultura del Santo Rey sobre la urna que contiene sus restos, a los lados las imágenes de San Isidoro y San Leandro y más arriba, en sus correspondientes hornacinas, las de Santa Justa y Rufina. El espacio de la urna se complementaba con una serie de pinturas alusivas a las gestas reales. No puede confundirse este proyecto de reforma profunda del presbiterio, con el retablo actual, realizado a partir de 1643 por Luis Ortiz de Vargas, a todas luces de menor empaque que lo proyectado una década antes.

24 Torre Farfán, 1672: 9

25 Quiles, 2007: 44-45. 
venir, el tipo de decoración que se pretendía realizar, así como sus costes con el fin de presentar toda la documentación al cabildo. Sin embargo, el 1 de abril, determinó la junta que la fiesta grande para el rey santo no durase más que un día, además de que en la capilla mayor "no se haga altar de architectura sobrepuesto y que se traiga a la diputación todo lo concerniente al adorno de la iglesia y de las puertas de San Cristóbal y de los Naranjos" ${ }^{26}$. El día 4 del mismo mes se vuelve a insistir en que el altar mayor solo se adorne con los ornamentos y frontales del Corpus ${ }^{27}$. En esa misma fecha se acordaron las decoraciones que se iban a colocar en el crucero, en la capilla real y en el resto de las capillas del recinto así como en el Patio de los Naranjos y La Lonja. Aparte se decidió el adorno de la Giralda, la procesión y los fuegos artificiales.

El ornato catedralicio más relevante se situó en la Capilla Real y en el trascoro, donde se iba a colocar un triunfo. La Capilla Real se decoró con paños de terciopelo y damasco adornados con castillos y leones y, sobre el friso, una inscripción latina alusiva al nuevo santo. Para ese recinto el capitán de Infantería Francisco de Ruesta ( $i-1673)$, hijo del arquitecto y cosmógrafo de la Casa de Contratación Sebastián de Ruesta (¿-1669), realizó dos dibujos, uno que mostraba la Capilla Real tal y como estaba en aquellos momentos, y el otro manifestaba el lugar donde se debía colocar la nueva imagen del rey santo ${ }^{28}$.

Francisco de Ruesta fue geógrafo e ingeniero, así como piloto de la Casa de la Contratación desde 1633. Aunque participó en la guerra de Cataluña, volvió a Sevilla y debió de vincularse como su padre, a proyectos de la sede catedralicia, hasta su muerte en $1673^{29}$. Se conoce que gozó de un gran prestigio en la corte, lo que con toda posibilidad no pasaría desapercibido al cabildo, además de ejercer la cátedra de Artillería, Fortificaciones y Escuadrones y tener amplios conocimientos de arquitectura y de matemáticas. Desconocemos los dibujos que presentó Ruesta pero, si nos atenemos al grabado de Matías de Arteaga (1633-1704), donde se distinguen los decorados de la Capilla Real para esta efeméride, apreciamos que la nueva imagen del santo se colocó debajo de la Virgen de los Reyes, en la parte inferior del presbiterio, sobre un ara en lugar destacado correspondiente a la santidad adquirida. El rey presentaba su nueva iconografía, de pie cubierto con el manto y coronado, portando su espada en la mano derecha y el globo crucífero en la izquierda.

Pero sin duda, la decoración más interesante y novedosa del interior catedralicio fue el triunfo colocado en el trascoro ${ }^{30}$, al considerarse que en ese espacio podría tener mejor luz natural a través de la puerta que daba a poniente. Se encomendó su seguimiento a los canónigos Justino de Neve y a Juan de Loaysa, que formaban parte de la comisión encargada de las solemnidades ${ }^{31}$. No tuvieron más que un mes para desarrollar el proyecto, aunque el cabildo colaboró con ellos permitiéndoles que trabajasen incluso en las horas de obligado cumplimiento litúrgico. De ese aparato efímero existe abundante documentación, la más importante fue su imagen, que se dio a conocer en el libro de Torre Farfán, y dispone de numerosos estudios ${ }^{32}$. Según anticipamos, el primer intento de triunfo proyectado en la segunda quincena de marzo, fue desechado al proponerse un nuevo emplaza-

26 Documentos Varios, 18 de marzo 1671, BCC, Sevilla, Signatura, 33-200, f. 113. Se presentó la proposición a la diputación encargada de las decoraciones, que finalmente desechó la idea.

27 Documentos Varios, 4 de abril 1671, BCC, Sevilla, Signatura, 33-200, f. 113v.

28 Autos capitulares, 8 de abril de 1671, Archivo Catedral de Sevilla (ACS), secretaría, leg. 7119.

29 Pulido Rubio, 1950 (2 ${ }^{\mathrm{a}}$ ed.): 797-798. Bernabeu Albert, 1986.

${ }^{30}$ De la importancia y complejidad del mismo da buena cuenta Torre Farfán, superando a cualquier otro ornato dispuesto en la fábrica catedralicia, capilla real, sagrario, exteriores del complejo u otros ámbitos de la ciudad. Si nos fijamos, de un total de 343 páginas que componen las Fiestas de la Santa Iglesia, el triunfo ocupa 100 páginas del total y sus empresas se distribuyeron en 9 láminas.

31 Pineda, 1685. Arana de Valflora, 1791: 69-70. Cherry, 2011. Falcón Márquez, 2011. Remitimos igualmente los trabajos de G. Finaldi, P. Cherry y T. Falcón Márquez, contenidos en el catálogo de la exposición, Murillo ₹ Justino de Neve, G. Finaldi (ed.), Madrid, Sevilla, Londres, 2012. Wunder, 2017: 45-72 y 81-83. Sobre Juan de Loaysa puede verse su propio relato autobiográfico en Memorias sepulchrales de esta Santa Iglesia Patriarchal de Sevilla en epitaphios, capillas, entierros, BCC, Legajo 59-4-4 (manuscrito), fols. 310-321. Esta biografía serviría de base a Matute, 1887: 25-39. Méndez Bejarano, 1922: 380-381. Wunder, 2017: 85-86. Quiles, 2018: 282 y 284.

32 Ferrer Garrofé, 1982: 70-78. Gallardo de Ondovilla, 1983: 247-248. Bonet Correa, 1985; 1986. Moreno Cuadro, 1985. Mulcahy, 2010. Wunder, 2017: 83-86. 
Fig. 4. Juan de Valdés Leal y Bernardo Simón de Pineda. 1671. Diseño del triunfo para la celebración del nuevo culto concedido al Rey Fernando III. Pluma y aguada de tinta sobre papel verjurado. (C) BCC, BAS, "Documentos varios", sign. 33-200. F. 118.

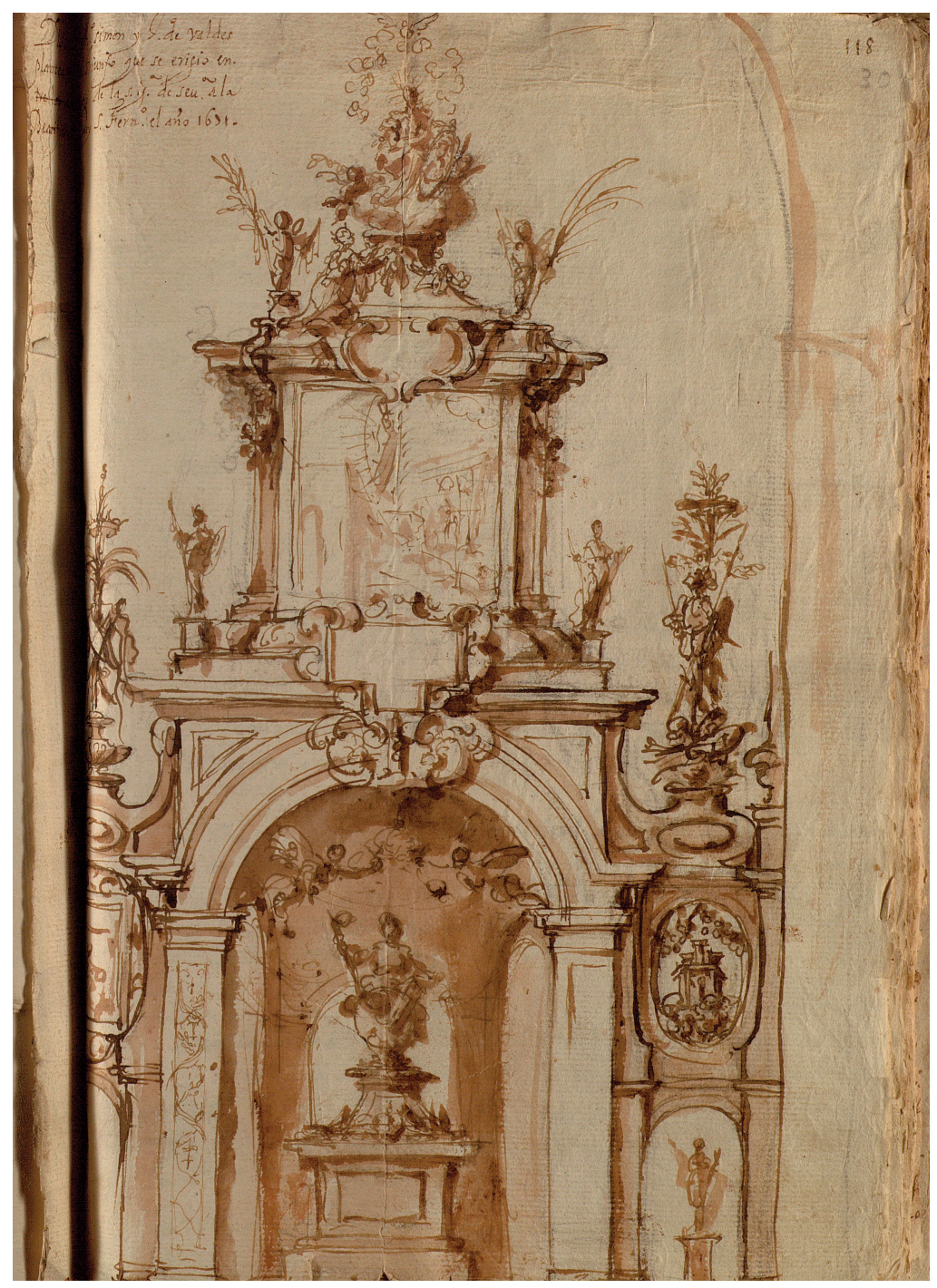

miento en el trascoro y, sin duda, estimarse que carecía de suficiente riqueza ornamental y arquitectónica. Se buscaba, en definitiva, una obra que innovara dentro del barroquismo que entonces impregnaba el ambiente cultural sevillano, digno de una conmemoración tan relevante ${ }^{33}$.

El dibujo inédito del primer proyecto de triunfo ideado por Bernardo Simón de Pineda y Juan de Valdés Leal, que ahora damos a conocer, se encuentra en el aludido volumen de varios de la Biblioteca Capitular y Colombina (sign. 33-200), procedente de la biblioteca del Arzobispado, integrado por diversos manuscritos de distinta índole y fechas. En el índice del citado legajo aparece el siguiente epígrafe: "Diseño para el triunfo en la Santa Iglesia en la beatificación del santo rey hecho por Bernardo Simón de Pineda insigne ensamblador y Juan de Valdés eminente pintor executose incomparablemente y su gasto paso de 18.000 ducados" ${ }^{\prime 34}$ [fig. 4]. Se trata de un dibujo a modo de "rasguño", realizado a pluma y aguada de tinta, de treinta y medio por veintiún centí-

33 Documentos Varios, 24 de mayo 1671, BCC, Sevilla, Signatura, 33-200, f. 118 El dibujo mide 31,5x21 cms.

34 Documentos Varios, 24 de mayo 1671, BCC, Sevilla, Signatura 33-200. El folio que aparece en el Índice es el 118, que es donde realmente se encuentra. Agradecemos a Pablo González Tornel, las indicaciones que nos dio sobre el dibujo aquí analizado. 
metros, donde se muestra una estructura, de planta cuadrangular, con cuatro arcos con bóveda interna. Este arco triunfal está configurado mediante un solo cuerpo, sobre el que aparece una tarja para la inscripción correspondiente y sobre él se apoya una estructura rectangular, a modo de pedestal con volutas laterales, rematado de forma similar al triunfo que finalmente se realizó, esto es, con un ático cuadrangular para incluir una pintura, culminado mediante un copete central y ángeles portando ramos a los lados. Aunque su estructura presenta ciertas similitudes con el triunfo que definitivamente se hizo, su configuración es menos compleja y ornamentada.

Sabemos por las actas capitulares del 24 de mayo, que la diputación nombrada por el cabildo para las fiestas, propone gastar 10.000 ducados para hacer un trofeo (triunfo) en el trascoro, cuyo pitipié debía ocupar el ámbito que hay entre los cuatro pilares donde se ponía el monumento, que debía elevarse a una altura de treinta y seis varas y dividirse en dos cuerpos ${ }^{35}$. Una descripción del monumento efímero proyectado, efectuada por los capitulares semanas antes, en el cabildo del 14 de abril, publicada por Quiles, indica el lugar que debía ocupar el trofeo, sus medidas, estructura y ornamentación, coincidentes con el dibujo que damos a conocer ${ }^{36}$. Los cuatro pilares de la fábrica entre los que se incluía la estructura festiva, debían decorarse con terciopelos y guirnaldas vegetales, marco de distintas empresas que fuesen de un pilar a otro. Sin embargo, no se alude a los arcos o arbotantes diagonales que debían contribuir a la sustentación del aparato efímero. Según esa descripción, el trofeo debía simular un arco triunfal cuadrifronte, adornado con distintas iconografías referentes a la vida, virtudes y victorias del santo, con guirnaldas o festones vegetales, pero en ningún caso se hace mención a los arcos en diagonal que, desde el núcleo central tenían la misión de derivar esfuerzos a los pilares de cantería, probablemente planeados con posteridad ante el evidente peso y riesgo de pandeo del grandioso trofeo. Esta fue la idea aprobada el citado día por el cabildo cuando, además, se cometió a don Justino de Neve y Juan de Loaysa para su disposición y gasto ${ }^{37}$.

Desde nuestro punto de vista, lo previsto entonces concuerda en lo esencial, con el dibujo que damos a conocer. Como se evidencia, se trata de un arco triunfal, sin que presente de forma explícita los cuatro arcos o arbotantes diagonales, que debían ir desde el templete central a los pilares, como describe Torre Farfán y aparece en el grabado de Matías de Arteaga. Se conseguía así la necesaria fortaleza del triunfo, al descargar parte de su peso en los pilares de la fábrica gótica, proveyendo a la vez nuevos marcos para las empresas y leyendas alusivas a san Fernando. Está claro que, entre la segunda quincena de abril y a lo largo del mes de mayo, no solo se pondría en pie el artefacto, sino que apresuradamente se introdujeron cambios en su estructura y elementos ornamentales, al tiempo que fue determinándose con asombrosa precisión su rica iconografía, laudatoria de las gestas y profundas convicciones cristianas del monarca medieval.

En el dibujo que presentamos se aprecia cómo el conjunto se estructuraba en tres calles, similares a los arcos triunfales de influencia romana utilizados en la ciudad, con motivo de visitas reales u otras efemérides. El arco central está sostenido por pilares y las calles laterales se destinaban a contener tarjas y esculturas alegóricas. Quizás estuvieran pensadas para su disposición en diagonal, conectando con los pilares del edificio, como luego se haría con el modelo definitivo, pero tal organización no queda reflejada en la traza que analizamos. Esas calles remataban en sendas volutas, a modo de contrafuertes, y sobre ellas figuran lo que aparentan ser victorias militares o panoplias. En el interior del templete aparece un alto pedestal sobre el que descansa un gran orbe y sobre él, una figura sedente femenina que sostiene algunos atributos que no se pueden apreciar con claridad. Podría tratarse de una alegoría de la Iglesia, triunfante en el mundo.

En los laterales se intuyen figuras con banderolas en el nicho inferior, y tondos con empresas o heráldica, uno de los cuales en el lado derecho prefigura un torreón o fortaleza, quizás alusivo a

\footnotetext{
35 Autos Capitulares, 24 de mayo 1671, ACS, Sevilla, Secretaría, Legajo 7119, f. 24v. En realidad, el triunfo venía construyéndose desde el mes de abril, y ahora a menos de una semana de las celebraciones, el cabildo procedería a la aprobación del importe desembolsado.

${ }^{36}$ Quiles, 2007: 45. La descripción está recogida de Autos Capitulares, 1671, ACS, Sevilla, Secretaría, Legajo 7119 , f. $26 \mathrm{v}$.

37 Autos Capitulares, 14 de abril 1671, ACS, Sevilla, Secretaría, Legajo 7119, f. 45.
} 


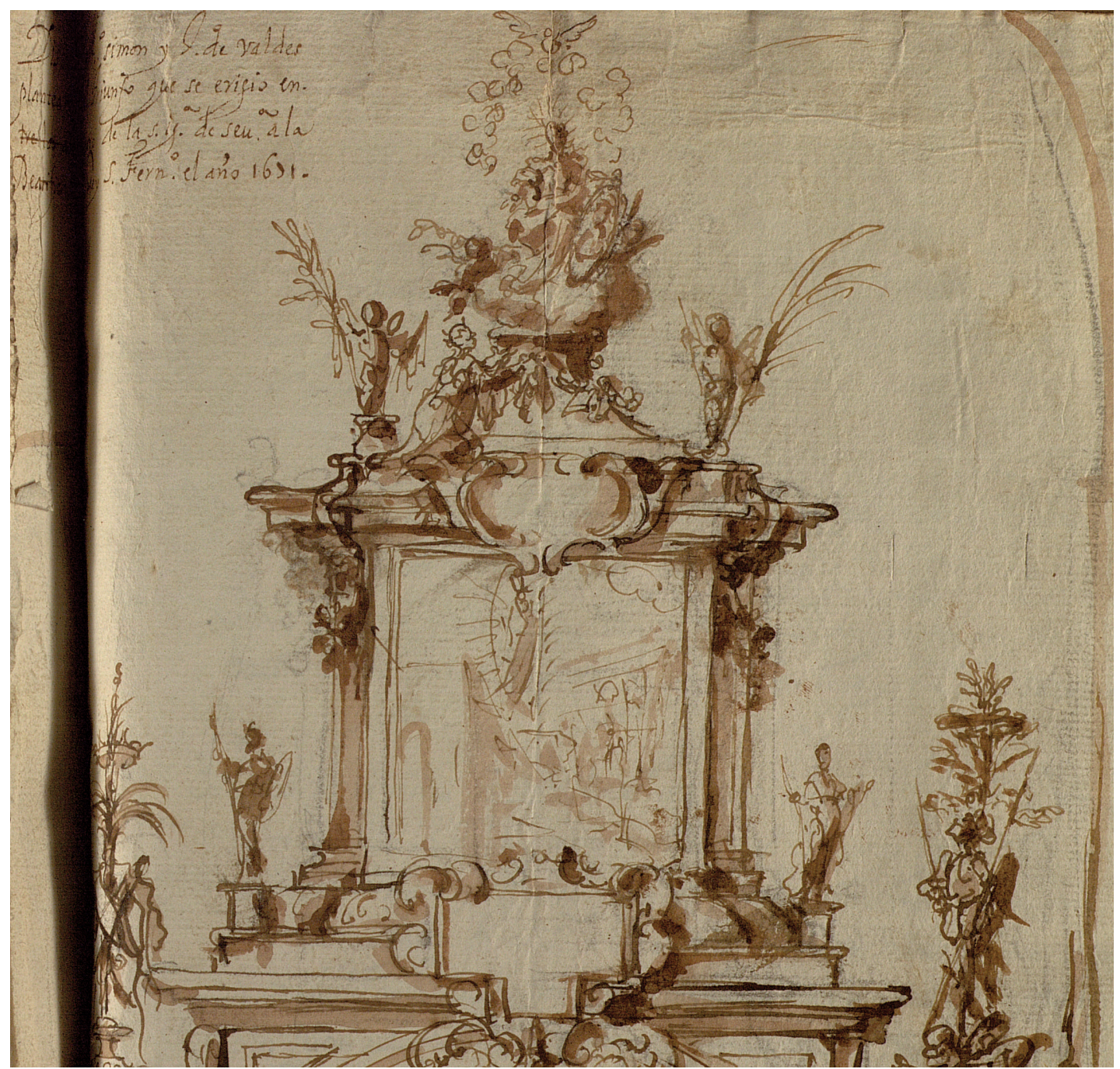

Fig. 5. Juan de Valdés Leal y Bernardo Simón de Pineda. 1671. Diseño del triunfo para la celebración del nuevo culto concedido al Rey Fernando III (detalle). Pluma y aguada de tinta sobre papel verjurado. (C) BCC, BAS, "Documentos varios", sign. 33-200. F. 118.

Castilla, mientras el del lado opuesto queda invisible por la encuadernación del volumen ${ }^{38}$. La parte superior descansaba sobre un pedestal y se estructuraba mediante un gran prisma central donde se puede apreciar, simulando una pintura, la imagen del santo al que se le aparece la Virgen dentro de una mandorla, posiblemente aludiendo a la aparición que presenció durante el sitio de Sevilla, o milagroso traslado por un ángel, ante la Virgen de la Antigua. A ambos lados se sitúan sendas esculturas y el remate se configura de forma ascensional destacando la composición, entre angelillos que portan palmas, del rey arrodillado con los brazos extendidos en actitud suplicante, bajo el remate compuesto por una imagen mariana sedente, que le muestra un retrato oval, quizás alusivo a una de las apariciones de la Virgen, que le anima a confiar en su imagen de la Antigua [fig. 5].

38 El dibujo, para adaptarse a las dimensiones del volumen donde se resguardó, fue recortado por la parte inferior, de manera que no se aprecian ni los pedestales de la estructura ni la escalinata sobre la que debe asentar el promontorio central. Además, el lado izquierdo está oculto por la apretada encuadernación del legajo, dificultando su apreciación al completo. 


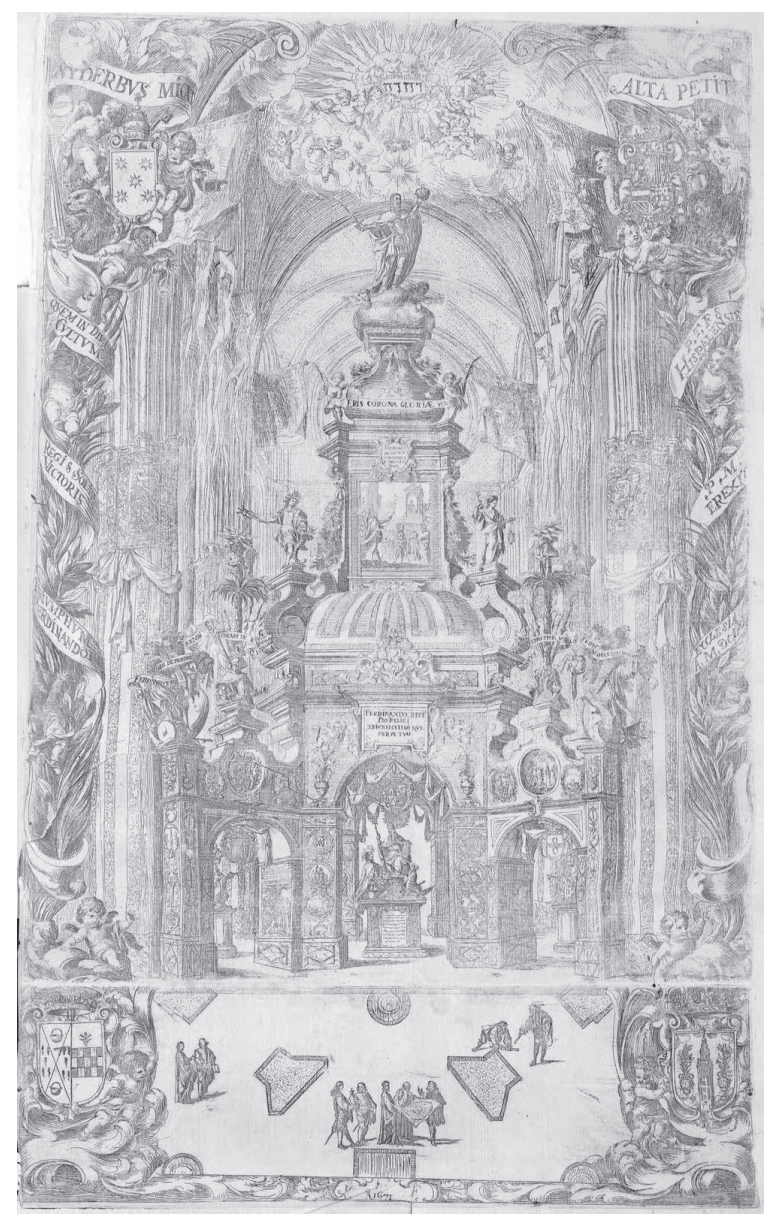

Fig. 6. Juan de Valdés Leal y Matías de Arteaga. 1671. Triunfo para la celebración del nuevo culto al rey Fernando III levantado en el trascoro de la catedral de Sevilla. Grabado calcográfico. F. de la Torre Farfán, Fiestas de la Santa Iglesia... (C) BNE, sign. INVENT/14544.
Lo más interesante de este proyecto es su diferencia con respecto al triunfo que finalmente se realizó. No tenemos constancia de los motivos que llevaron al cabildo a exigir una obra de mayor presencia, sin duda por el afán de deslumbrar al pueblo y dejar grabada en la memoria del mismo, la relevancia del nuevo santo asociado a Sevilla y su Catedral. Les parecería demasiado austera para la celebración, prefiriendo la estructura arquitectónica en la que se le añadía al templete central, los cuatro arcos a modo de arbotantes que iban a arriostrarse a los pilares del edificio. Es evidente que la arquitectura finalmente puesta en práctica resultó mucho más rica y compleja, que el primer proyecto cuyo dibujo está firmado por Valdés y Pineda. Como hemos dicho, el pago previsto para ese triunfo fue de 10.000 ducados pero, en el cabildo extraordinario del marte 3 de junio presidido por el deán, se afirmó que finalmente se le pagaron a los artistas 13.400 ducados porque el cabildo consideró "cuan excelentemente salió executada la idea del triunfo...y el sumo trabajo y desvelo con que perfecionaron la maquina $\mathrm{Ju}^{\mathrm{a}}$ de Valdes y Bernard ${ }^{\circ}$ Simon sus architectos" 39 . Además, se les pagaron a ambos artistas mil ducados de vellón de ayuda de costa.

El colosal triunfo finalmente realizado, descrito por Torre Farfán y grabado por Matías de Arteaga, ha sido sobradamente analizado ${ }^{40}$. Abundando en la na-

turaleza de la que debió ser inigualable obra efímera, dotada de modernidad barroca, alejada de concepciones tectónicas e imbuida por el acento ornamental y escenográfico, más que el propiamente arquitectónico, hemos de entender que Valdés y Pineda debieron ser asesorados por Justino de Neve, Juan de Loaysa u otros capitulares y eclesiásticos conocedores de los recursos que, desde tiempo atrás, eran habituales en las celebraciones festivas romanas [fig. 6].

No vamos a insistir en los intensos lazos que la iglesia sevillana mantenía con la cabeza de la cristiandad, donde disponía de agentes radicados allí de forma permanente, quienes no dejarían de inspeccionar el ambiente artístico y hasta enviarían libros, dibujos y grabados que cautivaran a los capitulares hispalenses y los pondrían a la vista de sus artistas. Ni mucho menos estamos ante una simple copia de modelos festivos romanos o italianos, pero no puede ignorarse la filiación con las propuestas emanadas de arquitectos y diseñadores como Carlo Rainaldi (1611-1691), muy requerido para las festividades que tanto empeño deparaban en la Roma seiscentista, especialmente procuradas por la nación española ${ }^{41}$. A Valdés y Pineda debieron sugestionarle algunos

\footnotetext{
39 Autos Capitulares, 3 de junio 1671, ACS, Sevilla, Secretaría, Legajo, 7119, 1671, f. 39v.

40 Ferrer Garrofé, 1983: 81-85.

41 Wittkover, 1937. Benedetti, 2012.
} 
Fig. 7. C. Rainaldi. Roma, 1653. Aparatos pirotécnicos para la proclamación de Fernando IV de Austria como Rey de Romanos. Grabado calcográfico. British Museum, Londres.

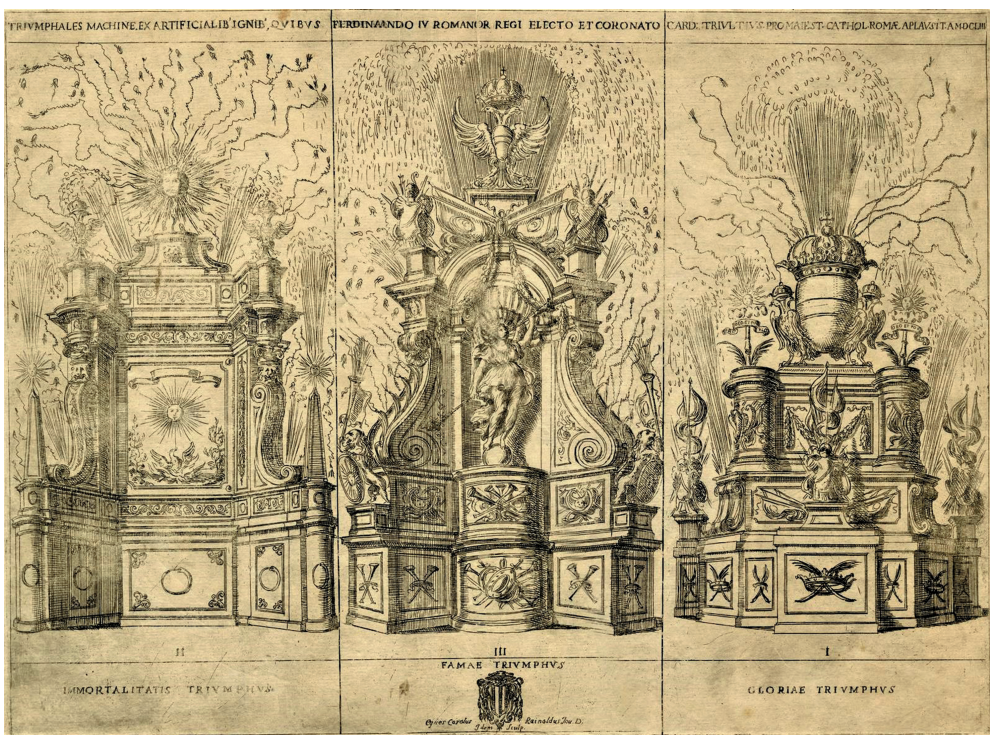

elementos conocidos a través de los cauces citados, entre otros los arcos laterales y volutas en diagonal, abarcando del espacio inmediato de portadas y tabernáculos, como vemos en la estampa que reproduce el arco de triunfo levantado por el duque de Parma para festejar la proclamación de Clemente X en 1670, los aparatos pirotécnicos para la proclamación de Fernando IV de Austria como Rey de Romanos, en 1653 [fig. 7], y en arquitectura real, en el interior de Santa Agnese in Agone, cuyos altares principales se encuentran flanqueados por machones oblicuos o en el proyecto para la portada de Santa María in Campitelli ${ }^{42}$.

Los motivos decorativos, epigramas y emblemas, parecen inspirados en la lujosa obra editada en Amberes en 1641, que reproduce los pórticos y arcos triunfales dispuestos en aquella ciudad belga en 1635, con motivo de la entrada del cardenal infante don Fernando (1610-1641) ${ }^{43}$, cuyos diseños y pinturas estuvieron al cuidado de Rubens (1577-1640), con gran difusión en la época, de manera que pudo servir de inspiración al cabildo sevillano o a Torre Farfán, para su texto e imágenes ${ }^{44}$. La obra era conocida en Sevilla, pues el canónigo Gaspar Murillo (1661-1709), hijo del pintor, disponía de un ejemplar en su biblioteca y Valdés Leal dejó testimonio de la misma, con una de sus páginas abiertas en la pintura del Hospital de la Caridad In Ictu Oculi de $1671^{45}$. Encontramos múltiples detalles repartidos por el vasto repertorio de imágenes antuerpiense, coincidentes con las realizaciones del equipo de Valdés y Pineda, como los tramos laterales en esviaje que componen el arco de bienvenida y felicitación de la ciudad al cardenal infante [fig. 8], las volutas provistas de peanas que vemos en los arcos dedicados a Hércules y San Miguel, sin olvidarnos del pórtico "cesáreo-austriaco", cuya concepción recuerda lo planteado en Sevilla para ornamentar el muro interno del Patio de los Naranjos y su Puerta del Perdón ${ }^{46}$.

Volviendo al fecundo caudal de imágenes romanas, añadimos la propuesta de tabernáculo de Giovanni Battista Montano (1534-1621), conservada igualmente en la $\mathrm{BNE}^{47}$, con alas laterales en diagonal [fig. 9], sin olvidar los proyectos de arquitecturas efimeras que se presentaban al cabildo

42 Fagiolo, 1997, t. 1: 2-9; Fagiolo, 1997, t. 2: 8-38.

43 Pompa Introitus honori serenissimi principis Ferdinandi Austriaci Hispaniarum infantis...Theod. a Thulden, Amberes, 1641. Biblioteca Nacional de España, (BNE), Madrid, Sign. ER/3347.

44 El primer en intuir tales influjos fue August Mayer, según señala Gállego, 1996: 147. Kubler, 1957: 94. Wunder, 2018: 93 y 171, n. 89.

45 Gué Trapier, 1960: 57-58. Wunder, 2018: 93.

46 Gué Trapier., láminas dispuestas entre las pp. 11 y 12; 42 y 43; 158 y 159; 162 y 163.

47 BNE, sign. DIB/18/1/883, Giovanni Battista Montano, Tabernáculo. Santiago Páez (dir.), 1991: 329-330. 


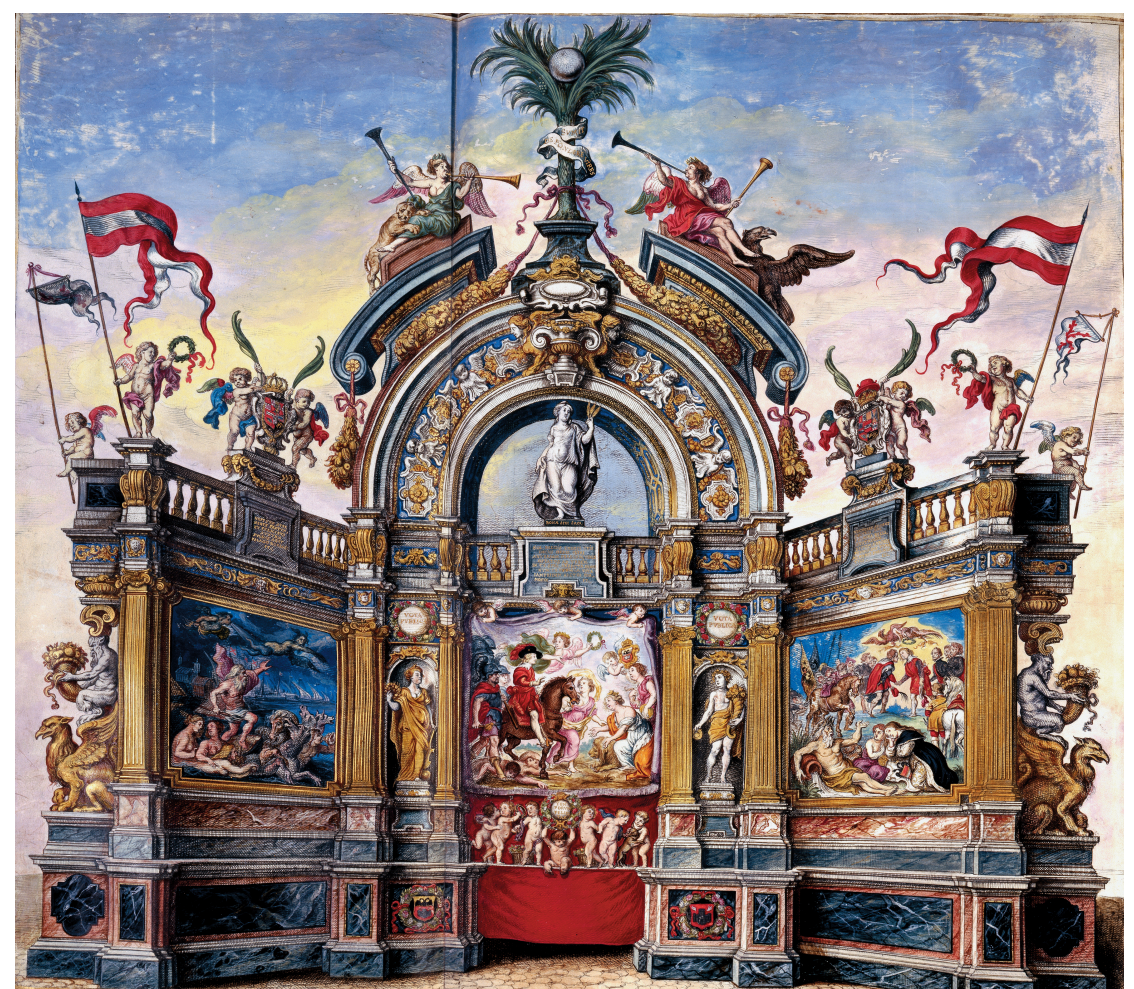

Fig. 8. P. P. Rubens. 1641. Arco triunfal de bienvenida y felicitación de la ciudad de Amberes al cardenal infante don Fernando. Grabado calcográfico coloreado con aguada de tinta. Th. a Thulden, Pompa Introitus Ferdinandi...@ BNE, sign. ER/3347.

con motivo de cualquier efeméride, que pudieron servir de inspiración para la realización de este triunfo. Concretamente aludimos al proyecto que hizo Hernán Ruiz II para las exequias del emperador Carlos V, en 1558, en cuya descripción se menciona las cuatro tirantas que para afianzar el túmulo se trabaron a los cuatro pilares del crucero, siendo aprovechadas para introducir ornato ${ }^{48}$.

Las cúpulas o remates bulboides, similares a los que presenta el triunfo grabado por Arteaga, los encontramos en los tabernáculos levantados en Piazza Navona para la celebración de la fiesta de la Resurrección, en 1650, evento patrocinado por la nación española, e igualmente podemos apreciar formas parecidas en el proyecto de la fachada este del palacio parisino del Louvre, de 1664, ambas del citado Carlo Rainaldi. Es posible igualmente aludir como sugerentes, los proyectos arquitectónicos realizados por Gian Lorenzo Bernini (1598-1680), concretamente el modelo para el campanario de San Pedro, uno de cuyos dibujos se conserva en la BNE ${ }^{49}$ [fig. 10], con remate bulboide semejante al del triunfo hispalense, que sirve de peana a la imagen victoriosa del Rey Santo. Las cúpulas seccionadas en diferentes paños fueron frecuentes en la Roma del momento, como se ve en algunas obras de Rainaldi, tales son las iglesias gemelas de la plaza del Popolo, Santa María in Montesanto y Santa María dei Miracoli ${ }^{50}$. Volviendo con las aludidas máquinas pirotécnicas del arquitecto romano ${ }^{51}$, en ellas también encontramos los grandes volutones y pedestales cilíndricos, como los que figuran frente a los arcos principales del triunfo fernandino. Con todo ello, en especial con los arbotantes en esviaje y pedestales cilíndri-

48 Lleó Cañal, 2012: 292, n. 103. Morales, 1988.

49 BNE, sign. DIB/14/46/40. Gian Lorenzo Bernini, Proyecto para el campanario de San Pedro. Santiago Páez, 1991: 121-122; Borsi, 1989: 60-63 y 218-224.

50 Wittkover, 1937. Luciani, 1991: 22-46.

51 Tozzi, 2006. 


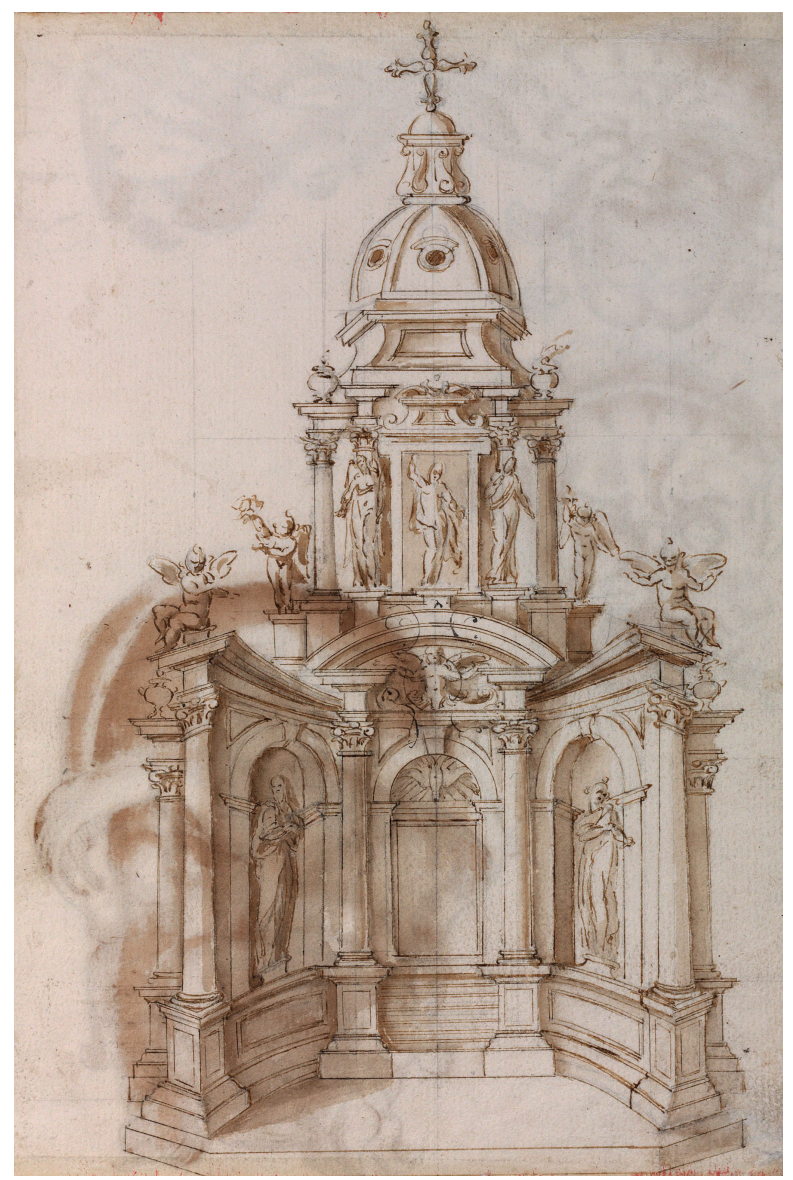

Fig. 9. G. B. Montano. 1600. Tabernáculo. Preparado a grafito, pluma y aguada de tinta sobre papel verjurado. (C) BNE, sign. DIB/18/1/883.

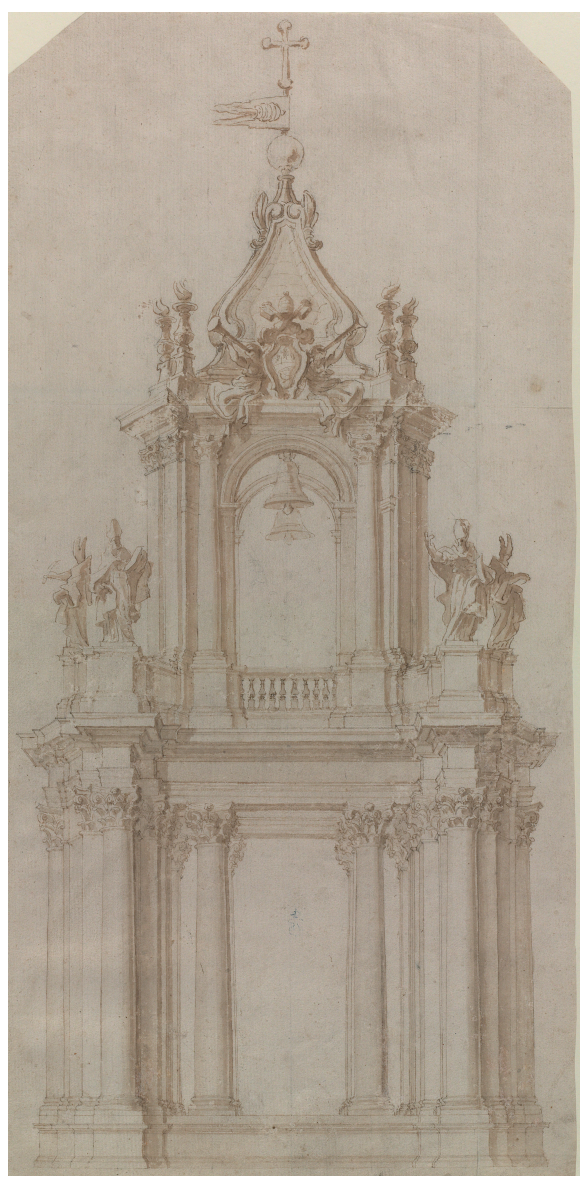

Fig. 10. G. L. Bernini. 1645-1646. Proyecto para campanario de San Pedro. Pluma, pincel, aguada de tinta sobre papel verjurado. (C) BNE, sign. DIB/14/46/40.

cos aislados, se procuraba la dilatación del espacio, que superaba el estatismo e individualidad de túmulos y arcos triunfales de momentos anteriores.

Valdés y Pineda no copian estampas concretas, pero se pone de manifiesto su capacidad para integrar elementos aislados extraídos de las creaciones italianas y flamencas, para producir un resultado original e innovador. El ambiente catedralicio, en permanente contacto con la ciudad de los papas, como puso de relieve todo el proceso para lograr la canonización del rey, estaba al día de las novedades constructivas y estéticas que se producían en Roma. Nada tiene de extraño que el propio discurrir de la fiesta de 1671, sus ornatos, pirotecnia, música, procesiones, lanzamiento de flores y vitelas entre los fieles, impresión de un libro ilustrado y el propio triunfo, estuvieran inspirados en las magnas celebraciones festivas romanas, como ha sugerido Amanda Wunder ${ }^{52}$. No hace falta insistir en ello, pero no está de menos recordar la singularidad y protagonismo del triunfo en la celebración festiva, como elemento clave del discurso ideológico y de la propia escenificación procesional y litúrgica, erigiéndose el monumento en máximo exponente de las virtudes, victorias y la gloria del rey ${ }^{53}$.

52 Wunder, 2017: 173-175. Refiere esta autora las similitudes con las fiestas de la beatificación en Roma, en 1668, de Santa Rosa de Lima, en el transcurso de las cuales fueron distribuidas entre los fieles abundantes estampas, pensadas para generar la devoción.

${ }^{53}$ García Bernal, 2006: 286. 
Según hemos expuesto, Bernardo Simón de Pineda y Juan de Valdés Leal hicieron al cabildo una primera propuesta que finalmente no se realizó. Entre la documentación existente sobre ese proyecto, no hemos encontrado el documento que aluda al rechazo. Posiblemente, la premura con la que se programó la fiesta de beatificación del santo rey, obligaría a decidir de inmediato el cambio de triunfo por uno de mayor riqueza y ornato. La estructura y decoración de ese primer proyecto nos remite a las obras de Bernardo Simón de Pineda realizadas en torno a la década de los setenta, salvo en la utilización del soporte salomónico. En relación con las fiestas fernandinas, puede equipararse formalmente al ornato interno de la principal de las puertas catedralicias ${ }^{54}$. Pineda fue el gran renovador de la retablística sevillana del siglo XVII ${ }^{55}$. El proyecto del triunfo que damos a conocer, se puede relacionar con el retablo mayor de la iglesia del Hospital de la Caridad de Sevilla (1670-1673), una de las obras maestras del barroco español ${ }^{56}$ y con las soluciones arquitectónicas del proyecto de retablo que hizo para la Capilla Real, salvo en la utilización del soporte salomónico ${ }^{57}$. Los elementos estructurales del proyecto rechazado se pueden comparar con la producción retablística de Pineda de esos años: marcos mixtilíneos, frontones partidos, empleo de figuras alegóricas, grandes volutas, tarjas con voluminosas decoraciones, etc.

Como consecuencia de todo lo expuesto, se pone de manifiesto que el cabildo catedralicio, durante los siglos del renacimiento y barroco en lo que a celebraciones solemnes respecta, aspiró a convertir la catedral hispalense en epicentro de la fiesta religiosa, procurando la magnificencia del culto, la liturgia y los cortejos procesionales. Todo ello unido a la máxima originalidad en las creaciones arquitectónicas, decorados efímeros, jeroglíficos y textos apologéticos. Así ocurrió en 1579, con motivo del traslado de los restos mortales de los personajes reales a su nueva capilla. Fallecido el arquitecto que había sido considerado por el cabildo de mayor relevancia, Hernán Ruiz II, se decidió encargar una obra efímera que volvía a recrear los principios arquitectónicos del maestro cordobés, todavía admitidos como preceptos de vigente actualidad, canalizados ahora a través de su seguidor Jerónimo Hernández. Este hecho nos lleva a pensar que los capitulares archivaron los proyectos de arquitecturas efímeras anteriores, que sirvieron de inspiración al nuevo encargo pues sabemos que Hernández hizo el proyecto en un solo día.

El mismo impulso y voluntad innovadora se volvió a manifestar un siglo después, con motivo de las fiestas al nuevo culto de san Fernando, en 1671. En este caso, además de lo comentado, se aprecia como el cabildo estuvo al tanto de las originales innovaciones artísticas llevadas a cabo en Italia y Países Bajos a través de embajadas, agentes, estampas y literatura festiva, todo ello traducido y adaptado por los grandes creadores del momento. Es evidente que la celebración de la santidad del conquistador de Sevilla, debía tener una proyección artística y decorativa parecida a la idea que tuvieron los canónigos para edificar la catedral, cuando pretendían que los que "la vieren labrada nos tomen por locos". Una vez más, el cuerpo capitular se dejó embriagar por las ínfulas megalómanas y propagandísticas en consonancia con su poderío material, aprovechando la ocasión para dar rienda suelta a fórmulas estéticas y alegóricas, de seguro éxito entre la ciudadanía y diferentes ámbitos religiosos y eclesiásticos.

\section{BIBLIOGRAFÍA}

Arana de Varflora, F. (1791): Hijos de Sevilla ilustres en santidad, letras, armas y dignidades. Sevilla: Vázquez, Hidalgo y Compañía.

Benedetti, S. (dir.) (2012): Architetture di Carlo Rainaldi nel quarto centenario della nascita. Roma: Gangemi Editore.

Bernabeu Albert, S. (1986): "Cualidades de los pilotos de la Carrera de Indias según el piloto mayor Francisco de Ruesta, 1669”. En: Revista de Indias, 46, 177, Madrid, pp. 331-344.

\footnotetext{
54 Torre Farfán, 1672: 123-132.

55 La bibliografía de este artista es muy extensa. Gran parte de ella está recogida en Halcón, Herrera, Recio, 2000: 223-236.

56 Valdivieso, Serrera, 1980: 19 y 54-55. Ferrer Garrofé, 1982: 26-28 y 51-66. Halcón, Herrera, Recio, 2000: 28-33 y 275; 2009: 228-230. Morales, 2007a.

57 Pleguezuelo Hernández, 1981.
} 
Bernales Ballesteros, J. (1973): Pedro Roldán, maestro de escultura (1624-1699). Sevilla: Diputación Provincial.

Bonet Correa, A. (1985): “Torre Farfán y las fiestas de la canonización de San Fernando en Sevilla, en 1671”. En: Torre Farfán, F. de la: Fiestas de la Santa Iglesia Metropolitana de Sevilla..., (ed. facsímil). Sevilla: Focus-Abengoa, pp. VII-XX.

Bonet Correa, A. (1986): "El poeta Torre Farfán y la fiesta de canonización de San Fernando en Sevilla, en 1671". En: Bonet Correa, A.: Andalucía monumental. Arquitectura y ciudad del Renacimiento y el Barroco. Sevilla: Editoriales Andaluzas Unidas, pp. 127-147.

Borsi, F. (1989): Bernini Architetto. Milán: Electa Editrice.

Castañeda Delgado, P. (1994): "Fernando III: el hombre y el santo". En: Archivo Hispalense, 234-236, Sevilla, pp. 401-416.

Cherry, P. (2011): "Palabras y obras pías: la biblioteca del canónigo Justino de Neve". En: Noble Wood, O. / Roe, J. / Lawrence, J. (dirs.): Poder y saber. Bibliotecas y blibliofilia en la época del conde-duque de Olivares. Madrid: Centro de Estudios Europa Hispánica, pp. 385-412.

Cintas del Bot, A. (1991): Iconografía del rey San Fernando en la pintura de Sevilla. Sevilla: Diputación Provincial.

Fagiolo, M. (1997): La festa a Roma dal Rinascimiento al 1870. Roma: Umberto Allemandi \& C.

Falcón Márquez, T. (2011): "El Canónigo Justino de Neve y la iglesia de Santa María la Blanca de Sevilla”. En: Laboratorio de Arte, 23, Sevilla, pp. 589-598.

Ferrer Garrofé, P. (1983): Bernardo Simón de Pineda. Arquitectura en madera. Sevilla: Diputación Provincial.

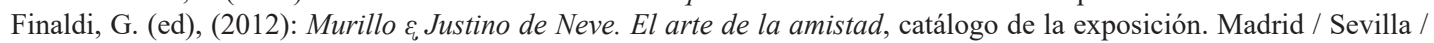
Londres: Museo del Prado, Fundación Focus-Abengoa, Dulwich Picture Gallery.

Gallardo de Ondovilla, P. (1983): "El triunfo". En: Sevilla en el siglo XVII. Sevilla: Ministerio de Cultura, pp. 247-248.

Gállego, J. (1996): Visión y símbolo en la pintura española del siglo de oro. Madrid: Cátedra.

García Bernal, J. (2006): El fasto público en la España de los Austrias. Sevilla: Universidad.

García Bernal, J. (2008): "Rito y culto de la monarquía filipina. El solemne traslado de los cuerpos reales de Fernando III y Alfonso X a la Capilla Nueva de Sevilla (1579)”. En: Revista de Humanidades, 15, Sevilla, pp. 171-197.

Gué Trapier, E. de (1960): Valdés Leal: spanish baroque painter. Nueva York: Hispanic Society of America.

Halcón, F. / Herrera, F. J. / Recio, A. (2000): El retablo barroco sevillano. Sevilla: Fundación El Monte.

Halcón, F. / Herrera, F. J. / Recio, A. (2009): El retablo sevillano desde sus orígenes a la actualidad. Sevilla: Diputación Provincial; Real Maestranza de Caballería; Fundación Cajasol.

Kubler, G. (1957): Arquitectura de los siglos XVII y XVIII. Madrid: Plus Ultra.

Laguna Paúl, T. (1998): "La aljama cristianizada. Memoria de la Catedral de Sevilla". En: Metropolis Totius Hispaniae. 750 aniversario de la incorporación de Sevilla a la corona castellana, catálogo de la exposición. Sevilla: Ayuntamiento de Sevilla, pp. 41-75.

Lleó Cañal, V. (2012): Nueva Roma, Mitología y Humanismo en el Renacimiento sevillano. Madrid: Centro de Estudios Europa Hispánica.

Luciani, Roberto (1990): Santa Maria dei Miracoli e Santa Maria di Montesanto. Roma: Palombi.

Matute, J. (1887): Hijos de Sevilla... t. II. Sevilla: Archivo Hispalense.

Méndez Bejarano, M. (1922): Diccionario de escritores, maestros y oradores naturales de Sevilla y su actual provincia. T. I. Sevilla: Gironés.

Menéndez Pidal, R. (ed.) (1955): Primera Crónica General de España que mandó componer Alfonso X el Sabio y se continuaba bajo Sancho IV en 1289, Madrid: Gredos.

Montoto, S. (1919): Traslación de la imagen de Nuestra Señora de los Reyes y cuerpo de San Leandro y de los cuerpos reales a la Real Capilla de la Santa Iglesia de Sevilla, año de 1579. Sevilla: La Exposición.

Morales, A. J. (1988): "Gloria y honras de Carlos V en Sevilla". En: AA. VV.: Seminario sobre arquitectura imperial. Granada: Universidad, pp. 148-157.

Morales, A. J. (2007a): "El más suntuoso sepulcro. Notas sobre el retablo mayor de la Santa Caridad de Sevilla". En: AA. VV.: Retablo Mayor de la Santa Caridad. Sevilla: BBVA, pp. 36-56.

Morales, A. J. (2007b): "Rey y Santo. Ceremonial por Fernando III en la Catedral de Sevilla". En: Mínguez, V. (ed.): Visiones de la monarquía hispánica. Castellón: Universitat, pp. 89-120.

Moreno Cuadro, F. (1985): "Humanismo y arte efímero hispalense: la canonización de San Fernando". En: Traza y Baza, 9, Córdoba, pp. 21-98.

Mulcahy, R. (2010): "Celebrating sainthood, government, and Seville: the fiestas for the canonization of King Ferdinand III”. En: Hispanic Research Journal, 11, 5, Dublín, pp. 393-414.

Ortiz de Zúñiga, D. (1988 reed.): Anales eclesiásticos y seculares de la muy noble y muy leal ciudad de Sevilla. T. 4. Sevilla: Ediciones Guadalquivir.

Pacho Sardón, U. (2015): "Singularidad del proceso de canonización de Fernando III el Santo". En: Isidorianum, XXIV, 47-48, Sevilla, pp. 227-252.

Pineda, Fray M. de (1685): Oración fúnebre en las honras que [...] se hizieron el sábado 7 de julio de este año de 1685 a la buena memoria del señor don Justino e Neve y Chávez... Sevilla: Juan de Loaysa.

Pleguezuelo Hernández, A. (1981): "Un proyecto de Bernardo Simón para el retablo mayor de la Capilla Real de Sevilla". En: Boletín Seminario de Arte y Arqueología, 47, Valladolid, pp. 335-344.

Pulido Rubio, J. (1950): El piloto mayor de la Casa de la Contratación. Sevilla: Escuela de Estudios Hispanoamericanos.

Quiles, F. (1999): "En los cimientos de la Iglesia sevillana: Fernando III, rey y santo". En: Boletín del Museo e Instituto “Camón Aznar”, LXXV-LXXVI, Zaragoza, pp. 203-249. 
Quiles, F. (2005): Por los caminos de Roma. Madrid: Miño y Dávila.

Quiles, F. (2007): Teatro de la Gloria. El universo artístico de la Catedral de Sevilla en el Barroco. Sevilla: Diputación Provincial.

Quiles, F. (ed.) (2018): Santidad barroca. Roma, Sevilla y América hispana. Sevilla: Universo Barroco Iberoamericano. Roda Peña, J. (2012): Pedro Roldán escultor 1624-1699. Madrid: Arco Libros.

Rodríguez Moya, I. (2006): "Fernando III, el Santo. Iconografía de la historia sacra de los reyes de España". En: Kunst, Ch. y Marsá, V. (eds.): Memoria y olvido de la historia. IV coloquio internacional del grupo de investigación histórica "Potestas". Castellón: Universitat Jaume I, pp. 99-127.

Rubio Merino, P. (2005): "Fiestas de la iglesia de Sevilla en la beatificación de San Fernando a través de los acuerdos del cabildo Catedral: año 1671”. En: Memoria Ecclesiae, XXVI, Madrid, pp. 183-231.

Santiago Páez, E. M. (dir.) (1991): Dibujos de arquitectura y ornamentación de la Biblioteca Nacional, siglos XVI y XVII. Madrid: Ministerio de Cultura.

Sigüenza, F. de (1996): Traslación de la imagen de Nuestra Señora de los Reyes y cuerpo de San Leandro y de los cuerpos reales a la Real Capilla de la Santa Iglesia de Sevilla, año de 1579. Sevilla: Fundación El Monte.

Torre Farfán, F. de la (1672): Fiestas de la S. Iglesia Metropolitana, y Patriarcal de Sevilla al nuevo culto del señor rey S. Fernando el tercero de Castilla y Leon.... Sevilla: Viuda de Nicolás Rodríguez.

Tozzi, L. (2006): "Carlo Rainaldi músico e architetto romano". En: Fagiolo, M. / Portoguesi, P. (ed.): Roma barocca. Bernini, Borromini, Pietro da Cortona. Milán: Electa, pp. 300-310.

Valdivieso, E. / Serrera, J. M. (1980): El Hospital de la Caridad de Sevilla. Sevilla: Diputación Provincial.

Wittkower, R. (1937): "Carlo Rainaldi and the architecture of the full Baroque". En: The Art Bulletin, 19, 2, Nueva York, pp. 242-313.

Wunder, A. (2001): "Murillo and the canonization case of San Fernando, 1649-1652". En: The Burligton Magazine, CXLIII, 1184, Londres, pp. 671-680.

Wunder, A. (2017): Baroque Seville. Sacred art in a century of crisis. University Park: The Pensylvania State University P.

Fecha de recepción: 29-VIII-2019

Fecha de aceptación: 29-X-2019 